\title{
Achtergronden bij een eventuele aanpassing van de teeltvoorschriften voor bewaring van suikerbieten en voederbieten
}

Martin Verbeek

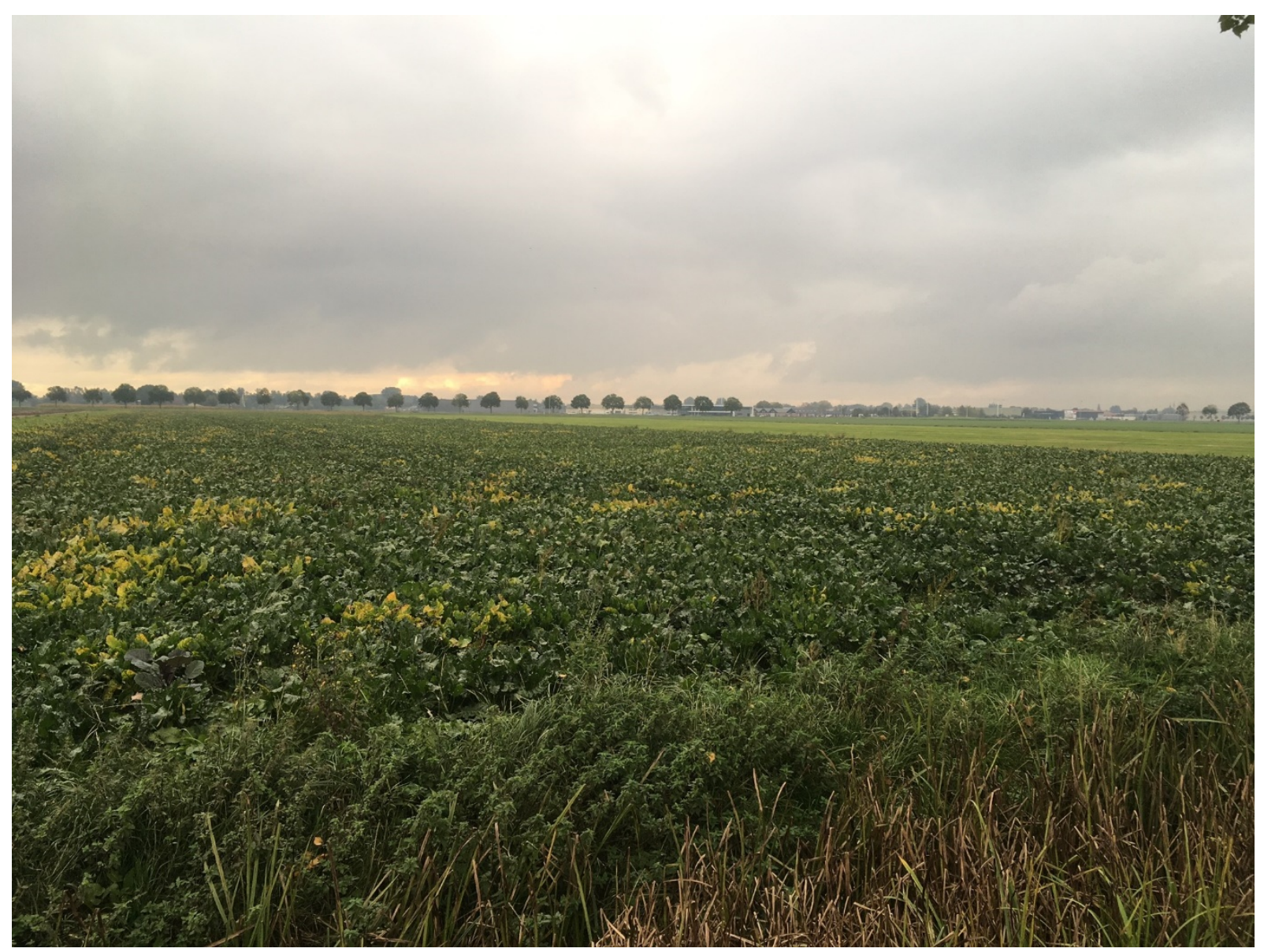





\section{Achtergronden bij een eventuele aanpassing van de teeltvoorschriften voor bewaring van suikerbieten en voederbieten}

M. Verbeek

Wageningen University \& Research

Dit literatuuronderzoek is in opdracht van het Ministerie van Landbouw, Natuur en Voedselkwaliteit uitgevoerd door de Stichting Wageningen Research (WR), Business Unit Biointeracties en Plantgezondheid, in het kader van beleidsondersteunend onderzoeksthema Teeltvoorschriften akker- en tuinbouw (BO-43-011.05-001).

WR is een onderdeel van Wageningen University \& Research, samenwerkingsverband tussen Wageningen University en de Stichting Wageningen Research.

Wageningen, mei 2021 
Verbeek, M., 2021. Achtergronden bij een eventuele aanpassing van de teeltvoorschriften voor bewaring van suikerbieten en voederbieten. Wageningen Research, Rapport WPR-3740087100-20-2.

Dit rapport is gratis te downloaden op https://doi.org/10.18174/545620

Om de verspreiding van bietenvergeling, veroorzaakt door bietenvergelingsvirussen, zoveel mogelijk tegen te gaan zijn teeltvoorschriften opgesteld, waarbij de aanwezigheid van opgeslagen bieten wordt verboden na een bepaalde datum. De teelt van voederbieten neemt de laatste jaren sterk toe, vanwege de goede eigenschappen als voer voor melkveerunderen. Doordat winters steeds milder worden vliegen de overbrengers van bietenvergeling, de bladluizen, ook steeds eerder. De vraag rijst dan ook of de datum waarna er geen bietenhopen meer op bedrijven mogen worden aangehouden vervroegd moet worden. Deze studie hoopt achtergronden aan te dragen voor een verantwoorde afweging van aanpassing van deze datum.

Trefwoorden: Suikerbieten, voederbieten, bietenvergelingsziekte, teeltvoorschriften, bladluizen

(C) 2021 Wageningen, Stichting Wageningen Research, Wageningen Plant Research, Business unit Biointeracties en Plantgezondheid, Postbus 16, 6700 AA Wageningen; T 0317480700 ; www.wur.nl/plant-research

KvK: 09098104 te Arnhem

VAT NL no. 8113.83.696.B07

Stichting Wageningen Research. Alle rechten voorbehouden. Niets uit deze uitgave mag worden verveelvoudigd, opgeslagen in een geautomatiseerd gegevensbestand, of openbaar gemaakt, in enige vorm of op enige wijze, hetzij elektronisch, mechanisch, door fotokopieën, opnamen of enige andere manier zonder voorafgaande schriftelijke toestemming van Stichting Wageningen Research.

Stichting Wageningen Research is niet aansprakelijk voor eventuele schadelijke gevolgen die kunnen ontstaan bij gebruik van gegevens uit deze uitgave.

Rapport WPR-3740087100-20-2

Foto omslag: Perceel suikerbieten met karakteristieke gele plekken veroorzaakt door bietenvergeling (Andel, oktober 2020) 


\section{Inhoud}

$\begin{array}{ll}\text { Samenvatting } & 5\end{array}$

1

$\begin{array}{ll}\text { Inleiding } & 7\end{array}$

2 Bietenvergelingsziekte $\quad 9$

2.1 De virussen betrokken bij bietenvergelingsziekte $\quad 9$

$\begin{array}{lll}2.2 & \text { Wijze van overdracht, de bladluis als vector } & 10\end{array}$

$\begin{array}{lll}2.3 & \text { Overwintering van vergelingsvirussen } & 11\end{array}$

3

$\begin{array}{lr}\text { Bladluizen } & 12\end{array}$

3.1 Levenscyclus van bladluizen 12

3.2 Veranderingen ten gevolge van het klimaat $\quad 12$

$\begin{array}{lll}3.3 & \text { Bladluisvluchten } & 13\end{array}$

$\begin{array}{lll}3.4 & \text { Kelder- en kuilluizen } & 17\end{array}$

4

$\begin{array}{lr}\text { Voederbieten } & 18\end{array}$

5

$\begin{array}{ll}\text { Teeltvoorschriften } & 20\end{array}$

6

Kennisleemten

22

6.1 De rol van kroten en voederbieten in de epidemiologie van bietenvergelingsziekte

\begin{tabular}{ll} 
& 22 \\
\hline
\end{tabular}

6.2 De rol van bewaarhopen in de epidemiologie van bietenvergelingsziekte 23

6.3 De effecten van de teeltvoorschriften en eventuele vervroeging van de datum waarop bewaarhopen niet meer zijn toegestaan $\quad 24$

$\begin{array}{ll}\text { Literatuur } & 25\end{array}$ 



\section{Samenvatting}

De suikerbiet kan worden aangetast door een tal van gewasbelagers en plantenziekten. Eén van die ziekten is bietenvergeling, dat vooral na het wegvallen van de zaadbehandeling met neonicotinoïden weer veel zichtbaar is in de bietenvelden. De bietenvergelingsziekte wordt veroorzaakt door verschillende bietenvergelingsvirussen die door bepaalde bladluissoorten worden verspreid. Om de verspreiding van bietenvergeling zoveel mogelijk tegen te gaan zijn teeltvoorschriften opgesteld waardoor het niet is toegestaan om een voorraad te hebben van suikerbieten en voederbieten, of afval ervan, wanneer er bladmateriaal op aanwezig is. Besmet bladmateriaal kan namelijk een bron zijn van waaruit bladluizen de virussen kunnen verspreiden. Dit geldt voor een groot gedeelte van Nederland vanaf 1 april en in een ander gedeelte van Nederland is dat 15 april.

Gezien de recente zachte winters en een duidelijk ingezette opwarming van het klimaat is de vraag gerezen of de genoemde datum van 1 april (of 15 april) niet vervroegd moet worden naar 1 maart i.v.m. het eerder en in grotere getalen aanwezig zijn van bladluizen. Deze vraag wordt verder geactualiseerd door de grote toename van de teelt, bewaring en het gebruik van voederbieten in de veeteelt.

De voorliggende studie is uitgevoerd om achtergronden te verzamelen bij de vragen naar de effecten van warmere winters op de levenscyclus van bladluizen en de eventuele effecten op de overdracht van bietenvergeling, dit in relatie tot het toenemend gebruik van voederbieten. Dit is voornamelijk uitgevoerd door middel van literatuurstudie, maar daarnaast zijn ook gesprekken gevoerd met onderzoekers van het IRS en WUR, met buitenlandse onderzoekers en adviseurs op het gebied van voederbieten van KWS en Limagrain. Ook zijn analyses uitgevoerd op vangstdata van bladluizen die door de NAK, IRS en Stichting De Groene Vlieg zijn uitgevoerd en beschikbaar gesteld voor deze studie. Hoewel deze data niet met het oog op deze analyses werden verzameld, konden wel aanwijzingen worden gevonden voor een vervroeging van bladluisvluchten in Nederland door zachtere winters. De conclusies van deze studie zijn:

- Zachtere winters hebben invloed op de levenscyclus van bladluizen waardoor deze minder als winterei overleven, maar als kolonie op kruidachtige planten. Zodoende zijn er al vroeg in het voorjaar kolonies aanwezig en zullen er zo bij gunstige weersomstandigheden bladluizen gaan vliegen.

- Hoewel er geen specifieke studies zijn gedaan naar de eerste vluchtdata van bladluissoorten is uit de waarnemingen van de NAK, Stichting De Groene Vlieg en IRS wel af te leiden dat migratievluchten van bladluizen al vanaf half maart zijn te verwachten.

- Bewaring van suikerbieten en voederbieten op hopen kan een bron vormen van vergelingsvirussen. Bladluizen kunnen deze virussen opnemen vanuit het blad, maar kuilluizen wellicht ook uit de wortels.

- $\quad$ Er is weinig informatie over de mate waarin kuilluizen in bietenhopen voorkomen, hier is meer studie nodig.

- Vanuit de rundveehouderij is een duidelijk signaal afgegeven dat vervroeging van de uiterste bewaardatum voor voederbieten naar half maart verdedigbaar is, maar dat een vervroeging naar 1 maart tot knelpunten kan leiden in de beschikbaarheid van vers voer (de vers-gras-periode begint eind maart).

Dit rapport beoogt de huidige kennis rond de verspreiding van bietenvergelingsziekte en de 
verandering die het opwarmende klimaat veroorzaakt te bundelen ter ondersteuning van mogelijke oplossingen om de verspreiding van bietenvergeling tegen te gaan en een eventuele aanpassing van de teeltvoorschriften met betrekking tot de bewaarperiode van suikerbieten en voederbieten. 


\section{$1 \quad$ Inleiding}

De suikerbiet is in Nederland de belangrijkste bron voor de suikerproductie, maar daarnaast ook voor grondstoffen voor de 'biobased' industrie. Daarbij is de suikerbiet één van de belangrijkste akkerbouwgewassen in ons land.

De suikerbiet kan worden aangetast door een tal van gewasbelagers en plantenziekten. Eén van die ziekten is bietenvergeling, dat vooral na het wegvallen van de zaadbehandeling met neonicotinoïden weer veel zichtbaar is in de bietenvelden. De bietenvergelingsziekte wordt veroorzaakt door verschillende bietenvergelingsvirussen die door bepaalde bladluissoorten worden verspreid. Om de verspreiding van bietenvergelingsziekte zoveel mogelijk tegen te gaan zijn teeltvoorschriften opgesteld. In deze teeltvoorschriften staat onder andere dat het in bepaalde perioden niet is toegestaan om een voorraad te hebben van suikerbieten en voederbieten, of afval ervan, wanneer er bladmateriaal op aanwezig is. Besmet bladmateriaal kan namelijk een bron zijn van waaruit bladluizen de virussen kunnen verspreiden. Dit geldt voor een groot gedeelte van Nederland vanaf 1 april en in een ander gedeelte van Nederland is dat 15 april (zie hoofdstuk 5). Deze maatregel is genomen om de kans dat bladluizen het virus overbrengen van de bewaarde bieten naar het nieuwe gewas te minimaliseren.

Gezien de recente zachte winters en een duidelijk ingezette opwarming van het klimaat is de vraag gerezen of de genoemde datum van 1 april (of 15 april) niet vervroegd moet worden naar 1 maart i.v.m. het eerder en in grotere getalen aanwezig zijn van bladluizen. Deze vraag wordt verder geactualiseerd door de grote toename van de teelt en het gebruik - en ook opslag - van voederbieten in de veeteelt. Het voeren van voederbieten heeft voor de veeteler grote voordelen, met name als de bieten vers kunnen worden gevoerd. De veeteler zal de voederbieten daarom zo lang mogelijk op het land laten staan, en daarna opslaan op het bedrijf tot ongeveer 1 april.

De voorliggende studie is uitgevoerd om achtergronden te verzamelen bij de vragen naar de effecten van warmere winters op de levenscyclus van bladluizen en de eventuele effecten op de overdracht van bietenvergelingsziekte, dit in relatie tot het toenemend gebruik en bewaring van voederbieten. De hoop is hiermee een ondersteuning te leveren voor een betere beheersing van bietenvergelingsziekte en een mogelijke onderbouwing van eventuele aanpassing van de teeltvoorschriften voor bietenvergeling.

De volgende personen hebben met hun kennis bijgedragen aan deze studie, waarvoor hartelijk dank:

E. Raaijmakers en M. Leijdekkers (IRS)

W. van der Werf (WUR)

A. Verhoeven en J. Roothaert (Limagrain)

M. Arts (KWS) 


\section{Bietenvergelingsziekte}

\subsection{De virussen betrokken bij bietenvergelingsziekte}

Bietenvergelingsziekte is een verzamelnaam voor ziekten die veroorzaakt worden door verschillende plantenvirussen: Beet yellows virus (BYV), Beet mild yellowing virus (BMYV) en Beet chlorosis virus (BChV) zijn daarvan de belangrijkste. Daarnaast komt het Beet mosaic virus (BtMV) sporadisch voor. Een ander vergelingsvirus genaamd Beet western yellows virus (BWYV) is nog niet in Europa waargenomen (Hossain et al., 2019). Deze vergelingsvirussen veroorzaken in de planten vergelingssymptomen door het afbreken van chlorofyl en de productie van gele en oranje pigmenten (fig.1). De fotosynthese-capaciteit van de bladeren vermindert en er hopen suikers en zetmeel op in de bladeren waardoor deze verdikken en broos worden. Infecties met vergelingsvirussen hebben een grote impact op de productie van suikerbieten (50-70\% oogstreductie zijn mogelijk) (van der Werf, 1988).

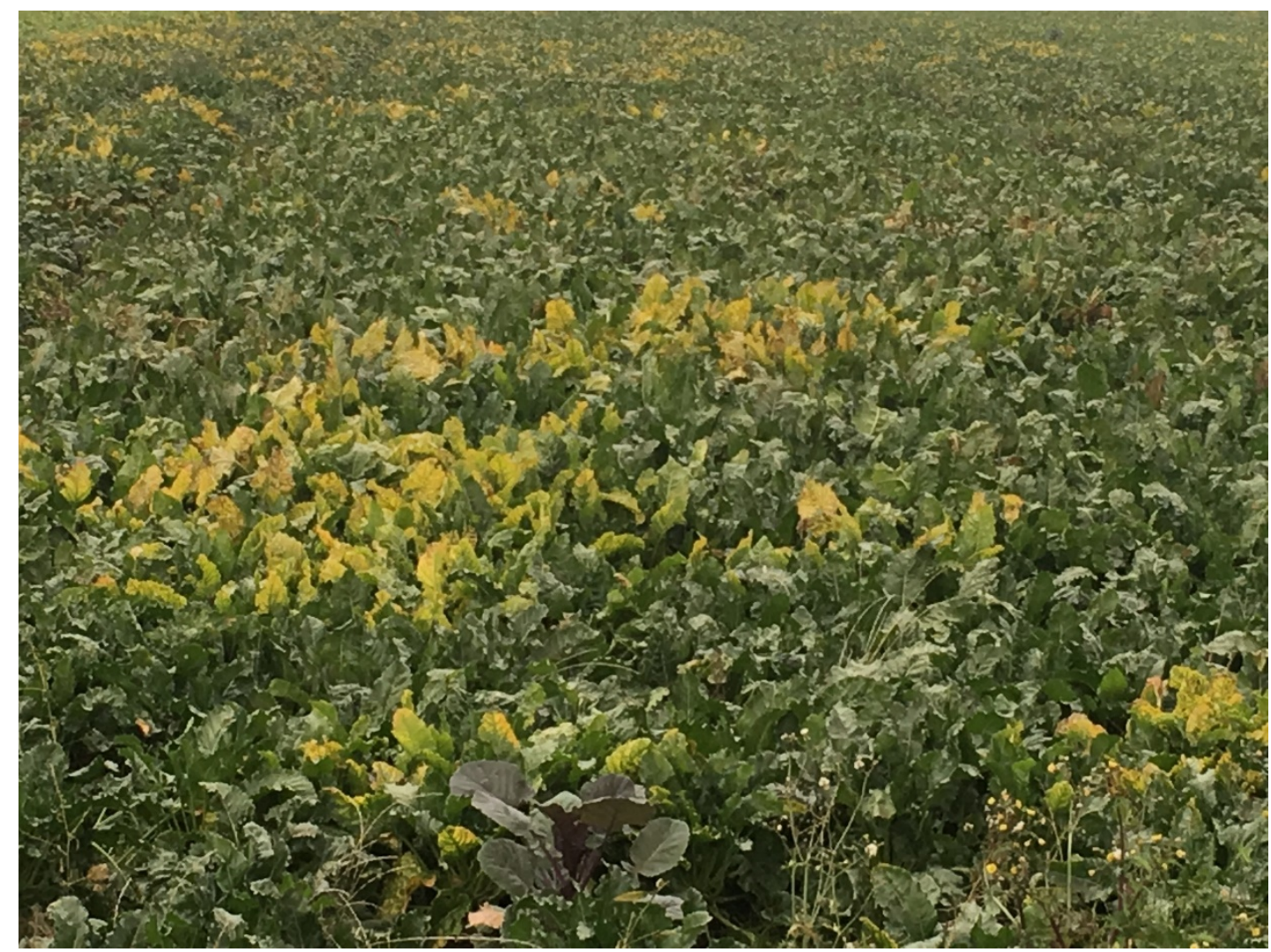

Figuur 1: duidelijke vergelingssymptomen in een suikerbietengewas (Andel, oktober 2020). 


\subsection{Wijze van overdracht, de bladluis als vector}

De wijze van overdracht van bij bietenvergeling betrokken virussen is gerelateerd aan de groep (geslacht) waartoe het betreffende virus behoort. De groep van Polerovirussen, waartoe BMYV en BChV behoren, wordt op een persistente wijze door bladluizen overgedragen. Deze manier van overdracht houdt in dat de bladluis het virus alleen via een voedingsboring kan opnemen, wanneer de stylet helemaal tot in het floëem is ingebracht. Een voedingsboring wordt door een bladluis alleen uitgevoerd nadat deze de plant na een paar proefboringen heeft geaccepteerd als geschikte waardplant. Het virus wordt daarna door het lichaam heen getransporteerd, waarbij het de darmwand en de lichaamsholte passeert, om uiteindelijk in de speekselklier terecht te komen. De bladluis is na opname daarom nog niet meteen in staat om het virus weer door te geven. Dit noemt men de latente periode. De bladluis blijft daarna wel voor haar verdere leven in staat planten te infecteren met het virus (mits ze genoeg heeft opgenomen) door het bij elke voedingsboring met het speeksel te injecteren in het floëem van de plant. Het virus vermeerdert zich niet in de bladluis (Gray and Gildow, 2003). Tevens is het doorgeven van dit soort virussen van de moederbladluis naar het nakomelingsschap nooit aangetoond (Hogenhout et al., 1996).

Het tot de groep van closterovirussen behorende BYV, ook wel sterk bietenvergelingsvirus genoemd, wordt op semi-persistente wijze door bladluizen overgedragen. Dat wil zeggen dat de bladluis minder lang infectieus is, maar nog steeds enkele dagen. Het virus hoeft ook niet de hele bladluis door te reizen, maar blijft binden in de styletten of slokdarm, van waaruit het weer terug wordt geïnjecteerd in de plant tijdens voedingsboringen (Jiménez et al., 2018; Limburg et al., 1997). Dit virus is weer aan een opmars bezig in Nederland (Persoonlijke mededeling E. Raaijmakers, IRS, fig. 2).

Het zelden voorkomend BtMV, een potyvirus, wordt op non-persistente wijze overgedragen. Deze manier van overdracht wordt gekenmerkt door een korte opnametijd van het virus door de bladluis. Dit gebeurt namelijk al tijdens zogenaamde proefboringen. Na enkele seconden of minuten is de bladluis al infectieus (er is geen latente periode) en zal bij een volgende proefboring het virus weer afgeven aan de plant (Katis and Gibson, 1984; Labonne et al., 1992).

Voor de drie manieren van overdracht van plantenvirussen door bladluizen (non-persistent, semipersistent en peristent) geldt dat er een specifieke binding tot stand moet komen tussen virus en de overbrenger van het virus (vector). Deze specifieke binding is niet voor alle virus-vector combinaties even sterk en is er de oorzaak van dat er grote verschillen zijn in efficiëntie waarop bladluissoorten (en zelfs daaronder liggende biotypen) virussen kunnen overbrengen (Peiffer et al., 1997; Verbeek et al., 2010). Voor de vergelingsvirussen in biet zijn voornamelijk de groene perzikluis (Myzus persicae), maar ook de sjalotteluis (M. ascalonicus), de aardappeltopluis (Macrosiphum euphorbiae), de zwarte bonenluis (Aphis fabae), en kuilluizen (o.a. Rhopalosiphoninus staphyleae tulipaellus) van belang (Heathcote and Cockbain, 1966; Heijbroek, 1984).

Een verschil in overdrachtswijze is van groot belang voor het schadebeeld dat ontstaat in het gewas. Een non-persistent overgedragen virus zal zeer verspreid door het gewas voorkomen. Immers, deze virussen worden door allerlei bladluizen overgedragen tijdens proefboringen. De overdragende bladluis hoeft het gewas niet tot waard te hebben, ze landen namelijk op allerlei planten en voeren proefboringen uit om te controleren of ze op een geschikte plant zijn geland.

Persistent en semi-persistent overgedragen virussen worden alleen door bladluizen overgedragen die het betreffende gewas als waard hebben. Een bladluis zal namelijk alleen een lange voedingsboring uitvoeren op een plant die het geschikt acht als waardplant die voldoende voedsel biedt en geschikt is om een kolonie te starten. Daarom is het schadebeeld van persistente virussen in een gewas meestal 


\section{Percentage vergelingsziekte in diagnostiekmonsters}

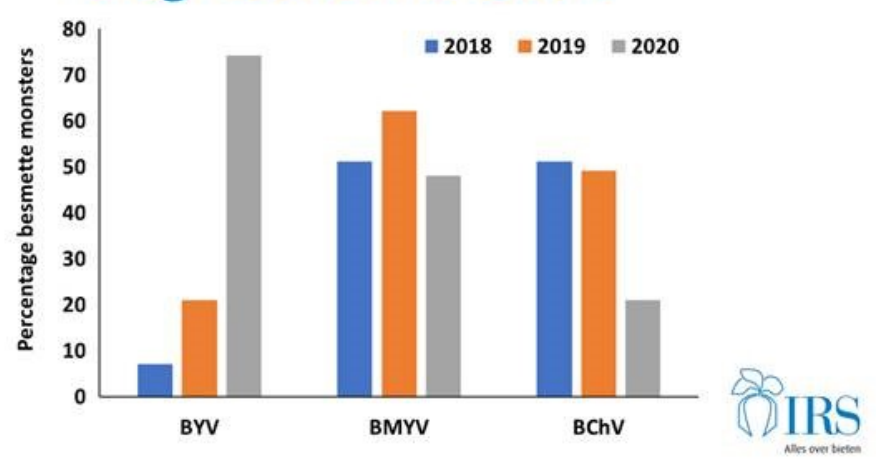

Figuur 2: Verdeling van vergelingsvirussen in diagnostiekmonsters van het IRS. Opvallend is de snelle opkomst van het sterk vergelingsvirus (Beet yellows virus, BYV).

\subsection{Overwintering van vergelingsvirussen}

Vergelingsvirussen van biet kunnen in opgeslagen suikerbieten, voederbieten en kroten overwinteren en worden verspreid als deze bewaarde bieten/kroten in het voorjaar weer uitlopen en het blad weer een bron vormt van waaruit het virus door bladluizen kan worden opgenomen (Heijbroek, 1984;

Stevens et al., 2005a). Daarnaast kunnen de virussen overwinteren in achtergebleven kleine bieten of bietenkoppen, die in zachte winters al uit kunnen lopen. Over het belang van kroten in de verspreiding van bietenvergelingsziekte zijn veel vragen. Als nauwe verwant aan de suikerbiet en voederbiet wordt de kroot of rode biet in de twee bovenstaande artikelen vermeld als waardplant voor bietenvergelingsvirussen. Echter, er is op dit moment geen informatie te vinden in hoeverre vergelingsvirussen in kroten symptomen of problemen kunnen veroorzaken en wat het belang is als bron van deze virussen. Ook navraag bij een veredelingsbedrijf met kroten in het assortiment leverde geen verdere informatie op.

Naast gecultiveerde bietensoorten komen vergelingsvirussen ook voor op andere, wilde planten waarin ze eventueel kunnen overwinteren, de zogenaamde winterwaarden.

BMYV kan overwinteren in wilde Beta-soorten maar ook in Capsella bursa-pastoris (Herderstasje), Cerastium fontanum (Hoornbloem), Stellaria media (Vogelmuur), Senecio vulgaris (Klein kruiskruid), Spergula arvensis (Gewone spurrie) en Veronica spp. (Ereprijs) (Heijbroek, 1984; Semal, 1956;

Stevens et al., 2005b; Stevens et al., 1994).

BChV kan zover bekend alleen Beta-soorten en Blitum (Chenopodium) capitatum

(Trosaardbeispinazie) infecteren (Stevens et al., 2005b), maar wilde Beta-soorten en Blitum komen nauwelijks in Nederland voor (https://www.nederlandsesoorten.nl).

Ook BYV heeft een kleine waardplantreeks en overwintert voornamelijk in wilde Beta-soorten (Hani, 1988), maar ook Stellaria media (Vogelmuur) wordt als waard van het sterke bietenvergelingsvirus genoemd (Heijbroek, 1984; Semal, 1956). 


\section{Bladluizen}

\subsection{Levenscyclus van bladluizen}

De levenswijze van bladluizen is op zijn minst complex te noemen. Normaliter vindt in de herfst een geslachtelijke voortplanting plaats die resulteert in het afzetten van wintereieren op een winterwaard (meestal een boom of struik). In het voorjaar komt dit winterei uit en wordt de stammoeder (fundatrix) geboren. De fundatrix gaat zich via parthenogenese vermenigvuldigen, dit wil zeggen dat er levende jongen worden geboren zonder dat hiervoor een geslachtelijke voortplanting voor nodig is. De geboren jongen zijn identieke kopieën (klonen) van de moeder. De gemiddelde levensduur van bladluizen is ongeveer één maand. Bladluizen worden volwassen na 4 tot 10 dagen (afhankelijk van o.a. temperatuur en kwaliteit waardplant) en beginnen dan meteen met het produceren van jongen. Een bladluis produceert dus wel drie weken lang nakomelingschap met gemiddeld 4 à 5 jongen per dag (Tsitsipis and Mittler, 1976). Pas in het najaar zullen er weer mannetjes en ei-leggende vrouwtjes ontstaan die voor de productie van wintereieren zullen zorgen (Hille Ris Lambers, 1972; Leather, 1993).

Er zijn bladluizen die alle stadia doorbrengen op dezelfde waardplant, maar de soorten die belangrijk zijn voor de verspreiding van bietenvergeling wisselen van waardplant. Hierbij zal de fundatrix eerst via parthenogenese jongen produceren die eerst ongevleugeld zijn, maar later ook jongen die vleugels krijgen. Deze gevleugelde bladluizen verlaten de houtige winterwaard om naar een geschikte secundaire, kruidachtige plant te vliegen. Wanneer de geschikte waardplant is bereikt zullen ook deze vrouwtjes via parthenogenese jongen produceren, ook eerst ongevleugeld, maar wanneer de kolonie te vol wordt worden opnieuw gevleugelden geproduceerd (Hille Ris Lambers, 1972; Leather, 1993). Er zijn verschillende factoren van invloed op de bladluisvluchten, zoals temperatuur(som), de mate van kolonievorming, wind en regen (Johnson, 1954). Dit is soortsafhankelijk zodat het mogelijk is voor bepaalde bladluissoorten separate vluchtpieken waar te nemen.

Naast de cyclus inclusief geslachtelijke voortplanting (ook wel holocyclisch genoemd) bestaat er ook een levenswijze waarbij de geslachtelijke voortplanting wordt overgeslagen en de bladluis zich het hele jaar door alleen via parthenogenese voortplant (anholocyclisch). Hierbij zullen de bladluizen dan niet meer migreren tussen zomer- en winterwaard, maar het hele jaar doorbrengen op gewassen en onkruiden die in de winter nog groene bovengrondse delen hebben.

\subsection{Veranderingen ten gevolge van het klimaat}

De laatste jaren zien we een trend in het steeds milder worden van de winters. Dit is goed te zien aan het zogenaamde koudegetal of Hellmanngetal. Dit Hellmanngetal is de som van alle daggemiddelde temperaturen onder nul in De Bilt zonder minteken. Dit is een goede maat voor hoe streng een winter was. In 1963 bereikte dit getal 337,2, de winter van 2010 bereikte nog 94,7, maar in de winter van 2019-2020 kwamen we niet verder dan 0,1 (https://www.knmi.nl/over-het-knmi/nieuws/zo-n-zachtewinter-wordt-heel-gewoon). 
Bladluizen kunnen - wanneer het geleidelijk kouder wordt en ze de tijd krijgen om hun lichaam aan te passen en stoffen aan te maken die als antivries werken - gemakkelijk een mate van vorst overleven (Leather, 1993). Het is al geruime tijd bekend dat sommige bladluissoorten, waaronder Myzus persicae, zonder geslachtelijke voortplanting en het leggen van een winterei de winter overleven (Walters, 1987). Door de steeds warmer wordende winters is het waarschijnlijk dat meer bladluizen (en bladluissoorten) een anholocyclische levenswijze volgen, waardoor er vroeger in het jaar kolonies aanwezig zijn van waaruit ook vroeger migratie zal plaatsvinden (Bell et al., 2015; Leather, 2015; Trebicki, 2020; Zhou et al., 1995). Er zullen dan ook eerder gevleugelde bladluizen in zulke kolonies aanwezig zijn en bij gunstige weersomstandigheden gaan vliegen. Deze gunstige weersomstandigheden zijn droog weer en een temperatuur die boven een voor die bladluissoort geldende grenswaarde ligt. Voor Myzus persicae is dit ongeveer $15^{\circ} \mathrm{C}$. (Heathcote and Cockbain, 1966), maar andere bladluizen kunnen ook al bij een lagere temperatuur gaan vliegen. Ook de sjalotteluis (Myzus ascalonicus) kan zo al heel vroeg in het jaar vliegen (zie figuur 3 ) en Semal rapporteert al in 1956 een sterke verdenking dat deze bladluis bietenvergeling vanuit vogelmuur kan overdragen naar suikerbieten (Semal, 1956).

Naast het vroeger optreden van bladluisvluchten, vinden er ook nog belangrijke vluchten in het najaar plaats. Deze vluchten zijn dan bij anholocyclische bladluizen niet meer de migratie van zomer- naar winterwaard, maar een migratie tussen zomerwaarden. Ook tijdens deze late vluchten wordt virus overgedragen. Asare-Bediako et al. vonden in het Verenigd Koninkrijk een relatie tussen een migratiepiek van de groene perzikluis tussen september en november en de overdracht naar winterkoolzaad van het Turnip yellows virus (TuYV), een aan BWYV en BChV gerelateerd virus (AsareBediako et al., 2020).

\subsection{Bladluisvluchten}

Een verandering in overwinteringsstrategie van bladluizen van holocyclisch naar anholocyclisch zal vermoedelijk te zien zijn in een vervroeging van bladluisvluchten. Immers, wanneer bladluizen als een kolonie de winter doorbrengen op kruidachtige gewassen, zal de koloniedruk op deze planten al vroeg in het voorjaar groot worden waardoor gevleugelde individuen worden geboren en de migratie naar nieuwe waardplanten op gang komt. Dit zal veel sneller gebeuren dan in de situatie waarin eerst een fundatrix (stammoeder) uit een ei tevoorschijn komt op een houtige winterwaard.

In Nederland worden bladluisvluchten gemonitord. Als eerste voert de Nederlandse Algemene Keuringsdienst (NAK) bladluisvangsten uit tijdens het teeltseizoen van de pootaardappel. De vangsten worden uitgevoerd met drie hoge zuigvallen (waarmee vliegende bladluizen worden gevangen op 12 meter hoogte) die zijn opgesteld in Kollumerwaard, Tollebeek en Colijnsplaat. Daarnaast staan er verdeeld over de pootaardappelgebieden in Nederland 38 gele vangbakken (die in het aardappelgewas zijn opgesteld en bladluizen vangen die door de gele kleur worden aangetrokken). De bladluizen worden gevangen in de periode 1 mei tot en met 1 september, op soort gedetermineerd en geteld (https://www.nak.nl/aardappelen/bladluisinformatie). Daarbij worden de vangstgegevens van vijftien voor de overdracht van het Aardappelvirus Y (PVY) belangrijke bladluissoorten verzameld en gebruikt voor het berekenen van de vectordruk voor dit aardappelvirus. Daarnaast worden vanaf half mei ook planten in het veld afgeklopt om zo de op het gewas aanwezige bladluizen te tellen.

Binnen de PPS virus- en vectorbeheersing in pootaardappelen (TU18049), waarin de NAK partner is, werd de periode van bladluisvangsten uitgebreid. Om een eventuele vervroeging van bladluisvluchten 
in beeld te brengen is het begin van de vangstperiode met een maand vervroegd naar 1 april. Op die datum in 2019 en 2020 werden de hoge zuigvallen aangezet, en op dezelfde locaties werden ook bladluizen gevangen met de gele vangbak en een bladluisfuik. In deze twee jaren werden in die vervroegde periode (van 1 april tot 1 mei) al bladluizen gevangen van belangrijke vergelingsvirusoverdragende soorten, zoals de groene perzikluis, de sjalotteluis, de aardappeltopluis en de zwarte bonenluis (zie figuur 3). Ook is in deze figuur te zien dat voor de groene bladluizen het jaar 2020 nog vroeger begon dan 2019, maar dat dit niet gold voor de zwarte bonenluis. Let wel: dit is een indicatie voor de drie plaatsen waar de vallen staan opgesteld, dit kan anders zijn op andere plaatsen.
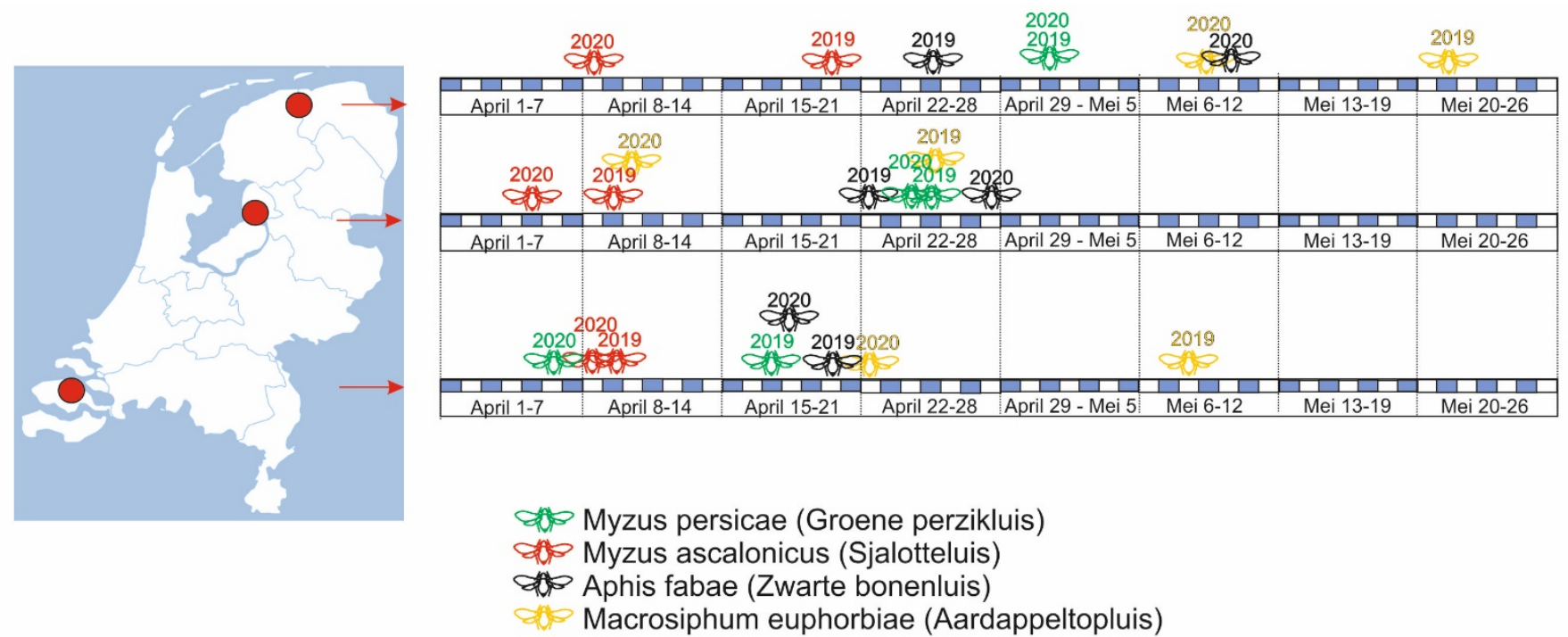

Figuur 3: Overzicht van de eerste waarnemingsdatum in 2019 en 2020 van vier voor bietenvergelingsziekte belangrijke bladluizen (de 'groene bladluizen' en de zwarte bonenluis). Deze waarnemingsdata zijn vermeld voor de locaties Colijnsplaat (Zeeland), Tollebeek (NOP) en Kollumerwaard (Friesland). De aangegeven datum is de dag waarop voor het eerst een vliegende bladluis van die bepaalde soort is gevangen, ongeacht het valtype (hoge zuigval, gele vangbak of fuik). Deze waarnemingen zijn in deze twee jaren gestart op 1 april binnen de PPS virus-en vectorbeheersing in de pootaardappelen, i.s.m. de NAK te Emmeloord.

Stichting De Groene Vlieg start in april, maar de laatste jaren ook al in maart, met de waarnemingen in tulpenvelden en gaat ook nog laat in het jaar door met vangsten in bijvoorbeeld de teelt van lelie. Er worden alleen totale aantallen bladluizen geteld en geen nadere soortsbepaling uitgevoerd. Stichting De Groene Vlieg heeft de vangstgegevens van 2013 t/m 2020 gedeeld met dit project en met de PPS virus- en vectorbeheersing. In Tabel 1 zijn de eerste vangstdata van bladluizen in tulpenvelden weergegeven voor drie teeltgebieden, t.w. ZuidWest (Zeeland, Zuid-Hollandse eilanden, West-Brabant), Polders (Flevoland) en Noord (Noord-Holland, Friesland, Groningen). Er zijn in deze reeks van jaren duidelijk vroege en latere jaren te zien voor wat betreft begin bladluisvluchten. Om te zien of de vroege jaren ook jaren waren die voorafgegaan werden door een zachte winter, is in dezelfde tabel het zogenaamde Hellmanngetal weergeven. Het Hellmanngetal (een optelling van alle etmaalgemiddelden beneden het vriespunt, bron KNMI) geeft in een getal weer hoe streng of zacht de winter was, gemeten van 1 november t/m 31 maart. Hoe hoger het getal, hoe strenger de winter. 
Hierbij dient te worden opgemerkt dat het aantal waarnemingen niet voldoende is om een echte correlatie tussen het Hellmanngetal en de vluchtdata aan te geven, maar het is hier slechts een indicatie.

Tabel 1: $\quad$ Eerste waarnemingsdata vliegende bladluizen door De Groene Vlieg in de jaren 2013 -2020 met het Hellmann Koudegetal voor desbetreffende jaren.

Datum eerste bladluisvangst tulpenpercelen (door St. De Groene Vlieg), bladluizen niet op soort gedetermineerd

\begin{tabular}{|c|c|c|c|c|c|c|c|c|}
\hline Streek/ jaar & 2013 & 2014 & 2015 & 2016 & 2017 & 2018 & 2019 & 2020 \\
\hline ZuidWest & 23 mei & 2 april & 30 april & 21 april & 26 april & 7 mei & 8 april & 16 maart \\
\hline Polders & $21 \mathrm{mei}$ & n.t. & n.t. & 18 april & 21 april & 7 mei & 1 april & 6 april \\
\hline Noord & $21 \mathrm{mei}$ & 7 april & 7 mei & $9 \mathrm{mei}$ & 19 april & $7 \mathrm{mei}$ & 15 april & 6 april \\
\hline Hellmann koudegetal & 73.2 & 0 & 7.8 & 9.6 & 36 & 34.1 & 12.1 & 0.1 \\
\hline
\end{tabular}

Het IRS analyseert ook bladluisvluchten. Allereerst gebeurt dit met de hoge zuigvallen in Colijnsplaat, Tollebeek en Kollumerwaard (i.s.m. de NAK), maar ook m.b.v. gele vangbakken in bietenpercelen. Deze vangsten worden ook door de NAK op soort gedetermineerd. Daarnaast worden door Cosun Beet Company en Delphy ook tellingen van bladluispopulaties in het veld uitgevoerd op bietenplanten. Deze bladluistellingen richten zich met name op de groene bladluizen (M. persicae, M. ascalonicus en $M$. euphorbiae). In figuur 4 staan als voorbeeld bladluisvangsten voor de groene perzikluis en tellingen van groene bladluizen weergegeven in het jaar 2019 in de plaatsen Axel en Spui (Zeeuws Vlaanderen). Opvallend is dat in deze plaatsen de eerste groene perzikluizen een paar weken later zijn gevangen dan in het iets noordelijker gelegen Colijnsplaat (zie figuur 3).

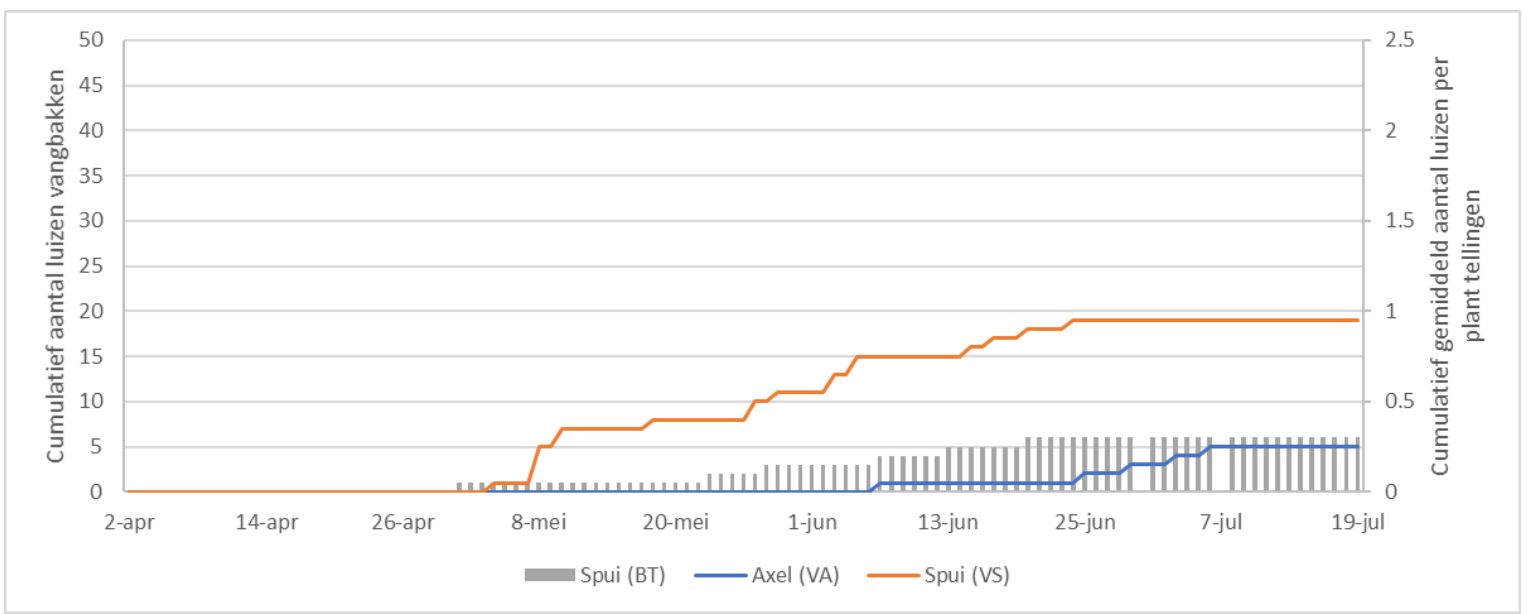

Figuur 4: Bladluistellingen door het IRS en Cosun Beet Company m.b.v. gele vangbak in aardappel (Axel, VA; blauwe lijn), gele vangbak in suikerbiet (Spui, VS; oranje lijn) voor M. persicae en door middel van bladluistellingen (groene bladluizen) in het suikerbietengewas (Spui, BT; grijze balken). Bron IRS (2019).

Het tellen van de groene bladluizen (Myzus persicae, M. ascolonicus en Macrosiphum euphorbiae) in het suikerbietengewas is van belang voor de vergelingsziektewaarschuwingsdienst. Deze waarschuwingsdienst begon in 1959 (met een proefjaar daaraan voorafgaand) met het uitbrengen van bladluisberichten en bespuitingswaarschuwingen op basis van tellingen volgens internationaal vastgestelde normen ( 1 telling per 200 ha bieten met een bespuitingswaarschuwing van meer dan 1 
groene perzikluis per 4 planten) (Heijbroek, 1984). De waarschuwingsdienst is een belangrijk hulpmiddel geweest in de beheersing van bietenvergelingsziekte tot aan de periode waarin het gebruik van neonicotinoïden als zaadbehandeling mogelijk werd. Na het verbod op deze middelen vanaf 2019 is de waarschuwingsdienst weer operationeel en worden er weer waarschuwingen afgegeven. De schadedrempels die nu worden gehanteerd zijn weergegeven in tabel 2 . Doordat de waarschuwingsdienst weer recent is opgestart is geen vergelijking te maken van waarschuwingsdata die in de afgelopen jaren zijn afgegeven.

Tabel 2: $\quad$ Schadedrempels voor bladluiswaarschuwingen bietenteelt (Bron IRS)

\begin{tabular}{lc} 
Periode & Aantal groene bladluizen per $\mathbf{1 0}$ planten \\
April, mei en eerste helft juni & Meer dan twee \\
\hline Tweede helft juni & Meer dan vijf \\
\hline Eerste helft juli & Meer dan vijftig
\end{tabular}

Tabel 3: $\quad$ Overzicht van bladluiswaarschuwingen per gebied in 2020 (Bron: website IRS https://www.irs.nl/alle/nieuws/1074-actuele-bladluissituatie-bladluiswaarschuwing-voorzeeuws-vlaanderen-west-brabant-zuid-voorne-putten)

\begin{tabular}{|c|c|c|c|c|}
\hline gebied & $1^{e}$ waarschuwing & $2^{e}$ waarschuwing & $3^{e}$ waarschuwing & $4^{e}$ waarschuwing \\
\hline Zeeuws-Vlaanderen & 23 april & 7 mei & 20 mei & 4 juni \\
\hline \multicolumn{5}{|l|}{ Zeeuwse Eilanden } \\
\hline Walcheren & 28 april & 7 mei & 20 mei & \\
\hline Noord-Beveland & 28 april & 7 mei & 20 mei & \\
\hline Zuid-Beveland & 28 april & 7 mei & 20 mei & 4 juni \\
\hline Schouwen-Duiveland & 28 april & 11 mei & 25 mei & \\
\hline Tholen/St. Philipsland & 28 april & 11 mei & 25 mei & \\
\hline \multicolumn{5}{|l|}{ West-Brabant } \\
\hline West-Brabant Zuid & 23 april & 11 mei & 25 mei & \\
\hline Rest West-Brabant & 28 april & 11 mei & 25 mei & \\
\hline \multicolumn{5}{|l|}{ Zuid-Hollandse eilanden } \\
\hline Voorne Putten & 23 april & 11 mei & 25 mei & \\
\hline Hoeksche Waard & 28 april & 11 mei & 25 mei & \\
\hline Goeree Overflakkee & 28 april & 11 mei & 25 mei & \\
\hline $\begin{array}{l}\text { Zuid-Holland } \\
\text { (incl. Haarlemmermeer) }\end{array}$ & $11 \mathrm{mei}$ & $25 \mathrm{mei}$ & & \\
\hline \multicolumn{5}{|l|}{ Noord-Holland } \\
\hline Noord-Holland vast & 7 mei & 20 mei & 4 juni & \\
\hline Texel & 28 mei & 25 juni & & \\
\hline Oost- en Zuid-Flevoland & 7 mei & 20 mei & 4 juni & \\
\hline Noordoostpolder & 14 mei & 28 mei & & \\
\hline Friesland klei & 20 mei & 25 juni & & \\
\hline Groningen klei & 14 mei & 4 juni & & \\
\hline Noordelijk zand & 11 juni & & & \\
\hline Noordelijk dal/veen & 11 juni & & & \\
\hline \multicolumn{5}{|l|}{ Gelderland e.o. } \\
\hline Bommelerwaard/Betuwe & 30 april & 14 mei & 4 juni & \\
\hline Rest Gelderland e.o. & 7 mei & & & \\
\hline \multicolumn{5}{|l|}{ Oost-Brabant } \\
\hline De Kempen & 30 april & 11 mei & & \\
\hline Rest Oost-Brabant & 7 mei & & & \\
\hline \multicolumn{5}{|l|}{ Limburg } \\
\hline Noord-en Midden-Limburg & 7 mei & & & \\
\hline Zuid-Limburg & 7 mei & 4 juni & & \\
\hline
\end{tabular}




\subsection{Kelder- en kuilluizen}

In - veelal wat oudere - literatuur wordt melding gemaakt van de aanwezigheid van de aardappelkelderluis (Rhopalosiphoninus latysiphon) en de kuilluis (Rhopalosiphoninus staphyleae subsp. tulipaellus, een ondersoort van de Pimpernootluis) in bietenhopen (Heathcote and Cockbain, 1966; Heijbroek, 1984). Deze bladluizen zijn vaak (ook in andere gewassen) te vinden op ondergrondse delen van planten en kunnen goed gedijen in bietenhopen. Ook M. persicae en andere bladluizen kunnen zich in de bietenhopen ophouden (Heathcote and Cockbain, 1966), maar zullen wel blad van uitgelopen bieten nodig hebben om zich in stand te houden. Toch wordt in het onderzoek van Heathcote en Cockbain in het Verenigd Koninkrijk aangetoond dat - doordat deze een betere vector is

- de meeste overdracht vanuit bietenhopen wordt veroorzaakt door de groene perzikluis. Daarnaast is de kuilluis ook een overbrenger van bietenvergelingsziekte, maar is overdracht door de aardappelkelderluis niet waargenomen.

Zodra de buitentemperatuur boven de 15 graden komt gaan zowel de groene perzikluis als de kuilluis vliegen en kunnen op die manier het in de bietenhoop aanwezige virus verspreiden naar naburige bietenplanten en/of onkruiden (Heathcote and Cockbain, 1966).

Op dit moment is de aanwezigheid van bladluizen en kuilluizen in bietenhopen, en hun rol in de overdracht van bietenvergelingsziekte, niet duidelijk. Navraag bij een aantal experts in binnen- en buitenland (Duitsland en Verenigd Koninkrijk) bracht aan het licht dat eigenlijk niemand hier naar kijkt of weet dat deze overdracht van in de bietenhoop overwinterende bladluizen een rol speelt.

Vluchtgegevens voor de kuilluis in Nederland zijn niet voorhanden omdat in bladluisvangsten alleen de vijftien soorten die belangrijk zijn voor de overdracht van het Aardappelvirus Y (PVY) worden geteld. Eventueel gevangen exemplaren van de kuilluis worden geschaard onder de 'overige bladluizen'. Om het belang van in bietenhopen en dus ook in voederbietenhopen overwinterende bladluizen goed in te kunnen schatten is een inventarisatie nodig naar hun aanwezigheid in deze hopen onder verschillende bewaarmethoden. 


\section{$4 \quad$ Voederbieten}

Onderstaande is een samenvatting van twee gesprekken met specialisten op het gebied van voederbieten: dhr. A. Verhoeven en dhr. J. Roothaert (Limagrain, 28 oktober 2020) en dhr. M. Arts (KWS, 5 november 2020). De gesprekken werden t.b.v. deze studie gehouden door M. Verbeek (WUR), E. Raaijmakers (IRS) en M. Leijdekkers (IRS, alleen 28-10).

De voederbiet is terug van weggeweest in het rundveebouwplan. Het areaal van de voederbietenteelt steeg in Nederland van 280 hectare in 2014 tot 2400 hectare in 2020. De voederbiet is zo populair omdat het voeren van voederbieten voor de rundveehouder grote voordelen biedt. Hieronder zijn de hoge opbrengst (ook in droge jaren), de zeer goede eigenschappen als voedermiddel voor runderen (smakelijk, melkdrijvend, vet- en eiwitgehalte verhogend), de besparing op krachtvoer en op het veld is de voederbiet een goede stikstof-binder (zelfs beter dan mais).

De rundveehouder zal proberen de voederbieten zo lang mogelijk vers te voeren. Daarbij blijven de voederbieten het beste zo lang mogelijk op het land staan en zal er dus gefaseerd worden geoogst. Oogsten in december, of in sommige gevallen in januari is mogelijk. De bieten worden dan direct gevoerd. Daarna moeten de bieten voor de rest van de voerperiode worden opgeslagen.

Veehouders die afhankelijk zijn van loonwerkers zullen soms beperkt zijn in de oogstmomenten en zullen de voederbieten al eerder moeten bewaren.

De bewaringsmethoden zijn:

a. Los gestort, bieten moeten kunnen blijven ademen, afdekken bij vorst (de hoop kan niet afgedekt blijven anders wordt de temperatuur te hoog).

b. Inkuilen met bv. snijmais, de bieten worden tijdens de maisoogst versnipperd over de maiskuil.

c. Inslurven/baggen: de bieten worden in een dichte 'slurf' gestort, hierbij is wel extra product dat als vochtvanger fungeert nodig om mee in te slurven (fig. 5).

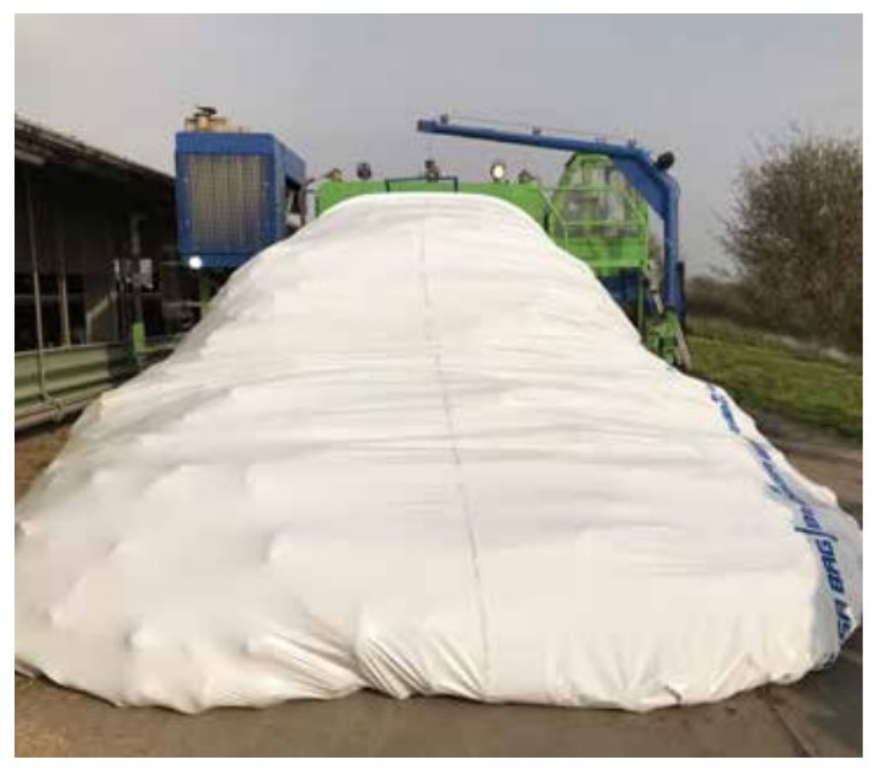

Figuur 5: Voorbeeld van "baggen" of "inslurven" van voederbieten. Bron: Limagrain, whitepaper voederbieten 2020 (https://www.Igseeds.nl/media//w/h/whitepaper voederbieten 2020 2.pdf) 
Daarbij moet worden opgemerkt dat de voederbieten het beste bewaard blijven als ze onbeschadigd zijn. "Koppen" zoals bij suikerbieten wordt gedaan is niet toepasbaar bij voederbieten. Er zal dus wel blad verschijnen op de bewaarde voederbieten, volgens de adviseurs is dit alleen boven op de hoop en dan vanaf half maart.

De veeteler zal voederbieten willen blijven voeren tot ongeveer 1 april omdat de vers-gras-periode pas eind maart begint. Zo blijft het seizoen van vers voer aaneengesloten. Volgens de adviseurs is het verbieden van het aanhouden van bietenhopen per 1 maart voor de veehouderij niet wenselijk, maar een vervroeging van het teeltvoorschrift om geen bietenhopen aan te houden naar 15 maart is verdedigbaar. De meeste veehouders hebben dan het grootste gedeelte van hun voederbieten opgevoerd. De voederbietenvoorraad die op dat moment over is kan eventueel dan nog versnipperd worden en ingekuild. 


\section{$5 \quad$ Teeltvoorschriften}

Om de verspreiding van vergelingsvirussen zoveel mogelijk te voorkomen zijn teeltvoorschriften opgesteld. Deze teeltvoorschriften omvatten richtlijnen voor de zaadteelt van bietensoorten (niet toegestaan in Flevoland, Zeeland en Noord-Brabant) en voor Groningen geldt dat er geen suikerbieten of voederbieten voor zaadwinning mogen worden geteeld in kassen. Daarnaast zijn er richtlijnen voor de bewaring van suikerbieten en voederbieten (zodra er bladvorming optreedt). In Groningen en Friesland moeten de bewaarde bieten voor 15 april worden opgeruimd, voor andere specifiek geduide gebieden in de rest van Nederland (gebied A in figuur 6) is die datum 1 april.

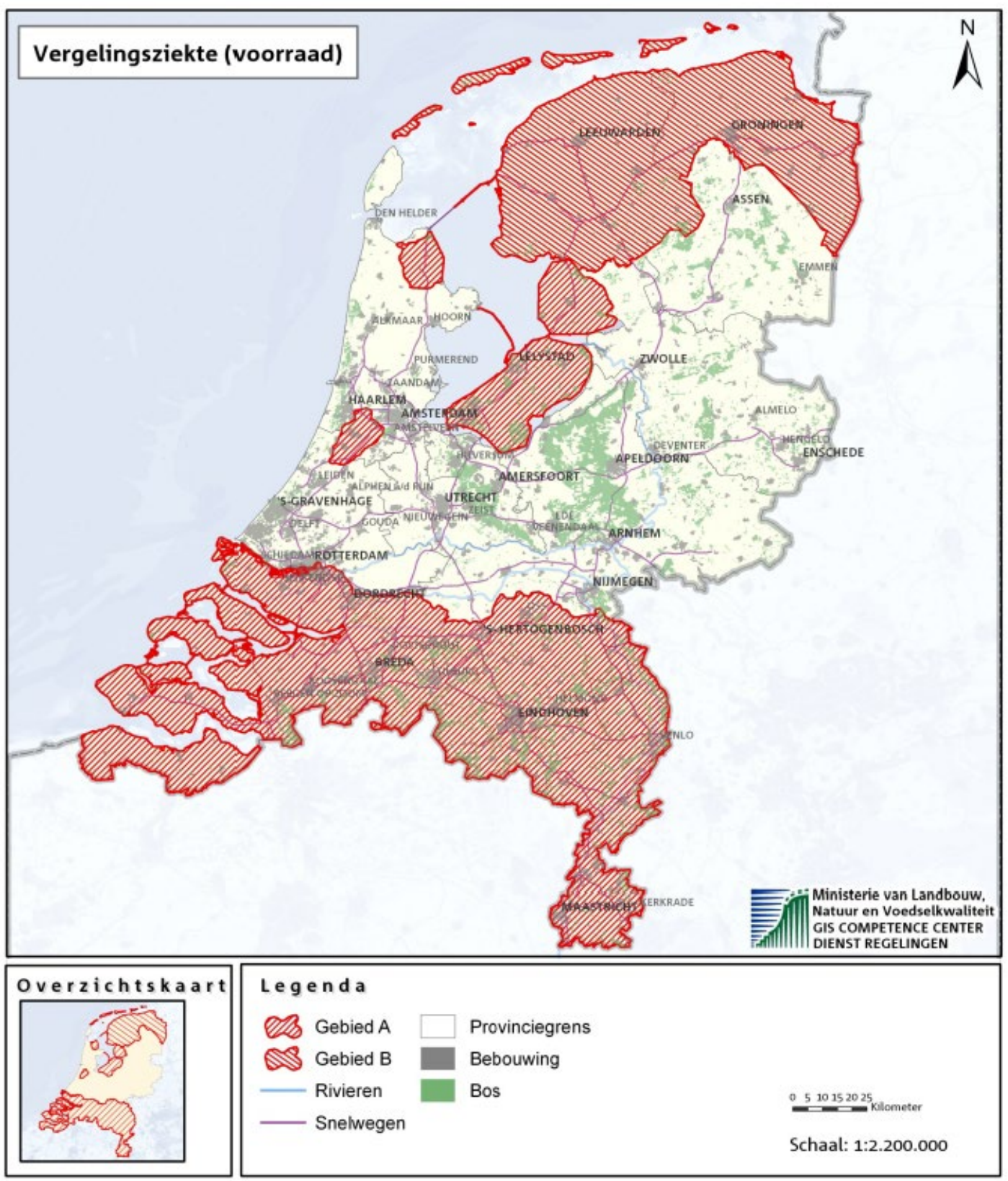

Figuur 6: overzichtskaart gebieden met teeltvoorschriftlen voor bewaring van bietenhopen (Bron NVWA). 
Doordat bieten steeds eerder worden gezaaid - het advies is nu zo snel mogelijk na 1 maart te zaaien, mits de grond dit toelaat - wordt het groeiseizoen langer en de opbrengst hoger

(https://www.irs.nl/userfiles/ccmsupload/ccmsart/IRS\%20informatie\%20febr\%2012\%20zaai\%20suik erbieten\%200p\%20tijd.pdf ).

Door de zachtere winters vliegen er ook al vroeg bladluizen die vergelingsvirussen kunnen overdragen. Het is dus zaak om ook al zo vroeg mogelijk bronnen van die virussen te verwijderen. Naast bepaalde onkruiden en opslag kunnen bewaarde suikerbieten en voederbieten een bron zijn. Door de vervroeging van de teelt en de aanwezigheid van bladluizen is de discussie ontstaan over een eventuele vervroeging van het teeltvoorschrift voor de bewaring van bietenhopen van 1 april naar 1 maart.

De nu voorliggende studie heeft als doel een beslissing over deze vervroeging van deze datum te ondersteunen. Uit deze studie komen de volgende punten naar voren:

- Zachtere winters hebben invloed op de levenscyclus van bladluizen waardoor deze minder als winterei overleven, maar als kolonie op kruidachtige planten. Zodoende zijn er al vroeg in het voorjaar kolonies aanwezig en zullen er zo bij gunstige weersomstandigheden bladluizen gaan vliegen.

- Hoewel er geen specifieke studies zijn gedaan naar de eerste vluchtdata van bladluissoorten is uit de waarnemingen van de NAK, Stichting De Groene Vlieg en IRS wel af te leiden dat migratievluchten van bladluizen al vanaf half maart zijn te verwachten.

- Bewaring van suikerbieten en voederbieten op hopen kan een bron vormen van vergelingsvirussen. Bladluizen kunnen deze virussen opnemen vanuit het blad, maar kuilluizen wellicht ook uit de wortels.

- $\quad \mathrm{Er}$ is weinig informatie over de mate waarin kuilluizen in bietenhopen voorkomen, hier is meer studie nodig.

- Vanuit de rundveehouderij is een duidelijk signaal afgegeven dat vervroeging van de uiterste bewaardatum voor voederbieten naar half maart verdedigbaar is, maar dat een vervroeging naar 1 maart tot knelpunten kan leiden in de beschikbaarheid van vers voer (de vers-gras-periode begint pas eind maart). 


\section{$6 \quad$ Kennisleemten}

De hierboven gerapporteerde studie is uitgevoerd in literatuur die via de bibliotheek van Wageningen University and Research is te benaderen. Hierbij valt op dat er weinig recente literatuur is over bijvoorbeeld epidemiologische studies naar bietenvergelingsziekte, maar ook studies naar gedrag en levenscyclus van bladluizen met betrekking tot bietenvergelingsziekte. Een aantal belangrijke vragen over de beheersing van bietenvergelingsziekte zijn vanuit die literatuur moeilijk te beantwoorden. Hieronder een aantal vragen waarvoor nog geen pasklare antwoorden voorhanden zijn.

\subsection{De rol van kroten en voederbieten in de epidemiologie van bietenvergelingsziekte}

Het gewas kroot (of rode biet) wordt in de literatuur een enkele keer expliciet genoemd als waard voor bietenvergelingsvirussen. Kroten kunnen, net als suikerbieten en voederbieten, voor langere tijd op hopen worden bewaard. Ook opslag door het uitlopen van achtergelaten kleine kroten in het volgend seizoen zou een probleem kunnen vormen als bietenvergelingsvirussen in deze planten aanwezig zijn. In de literatuur, maar ook bij navraag bij experts uit de praktijk van bieten en kroten, blijkt weinig bekend te zijn over bietenvergelingsziekte in kroten. In de literatuur wordt uitgegaan dat de aan de suikerbiet nauw verwante kroot vatbaar zal zijn voor de vergelingsvirussen, maar of dit ook ziektebeelden geeft wordt niet vermeld. Ook in veredelingsprogramma's van kroot werkt men niet aan resistentie voor deze virussen en de veredelaars die aan dit gewas werken melden geen problemen met vergelingsziekte. Het is dus ook niet bekend of kroot een symptoomloze drager kan zijn voor deze virussen.

Het is wel bekend dat vergelingsvirussen in voederbieten voorkomen, maar er wordt gezegd dat ziektebeelden meevallen. Om een indruk te krijgen van de rol van voederbieten bij de verspreiding van bietenvergelingsziekte speelt ook de vraag of voederbieten en suikerbieten wel in dezelfde gebieden worden geteeld. Het areaal voederbieten is de laatste jaren enorm gestegen en de verwachting is dat deze nog meer zal stijgen. Nu vindt die uitbreiding voornamelijk plaats bij melkveebedrijven, omdat de voederbiet voor het voeren van melkvee zeer geschikt is. De melkveehouderij is een sector die over het hele land verspreid voorkomt (van der Peet et al., 2018), maar het meeste melkvee komt voor in de donkerblauwe gebieden in onderstaande kaart (fig. 7A). De gebieden met de hoogste dichtheid veeteelt, en waar waarschijnlijk de meeste voederbieten geteeld zullen worden (maar dit is een aanname), komen niet overeen met de gebieden met de meeste teelt van suikerbieten (bron CBS, fig. 7B). Kijken we naar de tussenliggende gebieden, dan zullen er genoeg situaties zijn waar voederbieten en suikerbieten in elkaars nabijheid zullen worden geteeld. Hier zijn echter geen inventarisaties van gevonden in publicaties. 


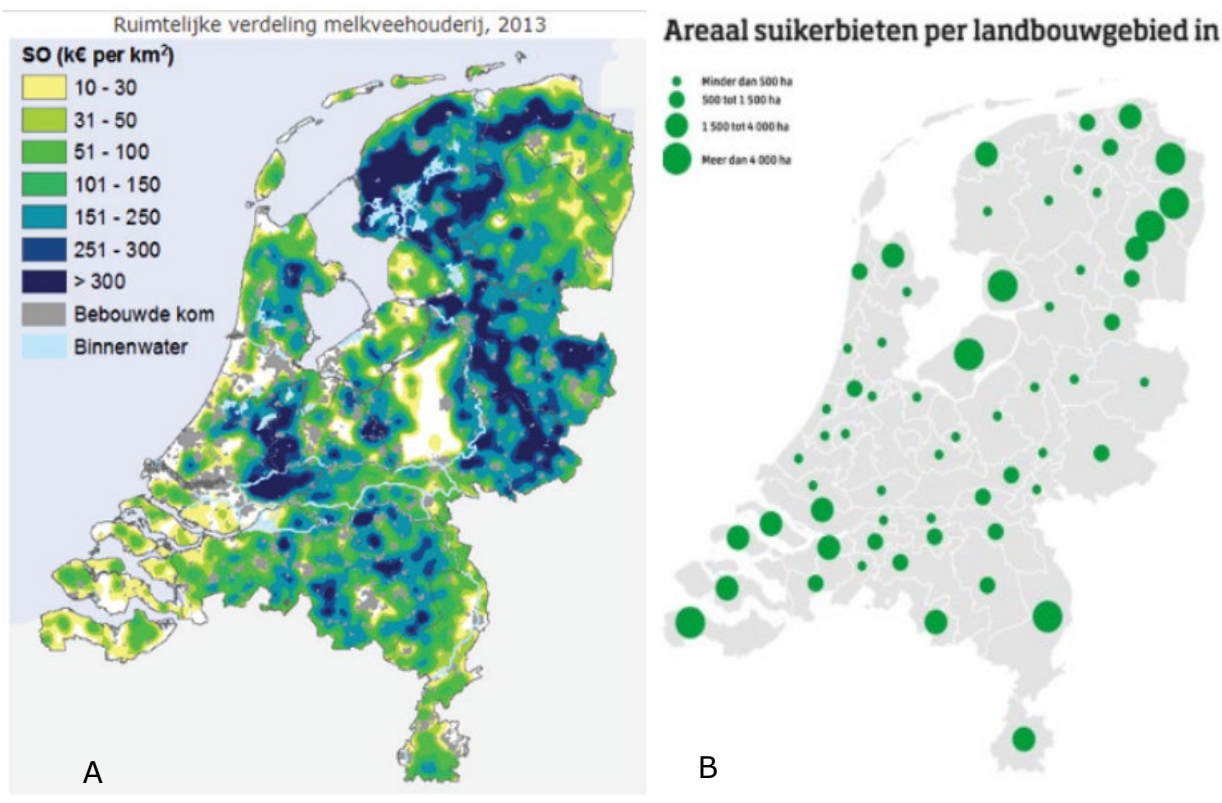

Figuur 7: A) overzichtskaart van de dichtheid van melkveehouderij (naar omzet per km2) (bron Van der Peet et al, 2018) en B) overzichtskaart van het areaal suikerbieten per landbouwgebied (bron CBS: https://www.cbs.nl/nl-nl/nieuws/2018/09/suikerbietenteelt-gegroeid).

\subsection{De rol van bewaarhopen in de epidemiologie van bietenvergelingsziekte}

Dat bewaarhopen van suikerbieten een bron van vergelingsvirussen kunnen zijn is al lang bekend, daarom zijn destijds ook de teeltvoorschriften in het leven geroepen om verspreiding van bietenvergelingsziekte tegen te gaan. Ook is bekend dat er ook andere verspreidingsroutes van deze virussen zijn, bijvoorbeeld vanuit onkruiden en opslag van op het land achtergebleven bieten. Toch is het vanuit de literatuur heel moeilijk om aan te geven welk belang in de totale verspreiding van de verschillende vergelingsvirussen deze bewaarhopen hebben. Dit heeft te maken met de betrokkenheid van verschillende virussen met verschillende overdrachtsmechanismen door bladluizen (persistent en semi-persistent). Ook zijn er directe interacties tussen de betrokken virussen en de overbrengende bladluizen, met verschillende efficiënties per bladluissoort (en zelfs biotypen binnen een soort). Ook is er weinig zicht op welke bladluizen nu precies in bietenhopen voorkomen en voor mogelijke verspreiding van de virussen zorgen. In de literatuur worden verschillende bladluizen genoemd, maar ook wortelluizen zoals de kuilluis. Recent onderzoek en recente waarnemingen zijn echter niet voorhanden, met name voor de kuilluis zijn geen gegevens bekend over het al dan niet aanwezig zijn in bewaarhopen. Dit ontbreken van kennis geldt ook voor de aantrekkelijkheid van bietenhopen voor de verschillende bladluissoorten.

Die kennis zou gebruikt kunnen worden bij het ontwerpen van maatregelen om bladluispopulaties in bewaarhopen tegen te gaan, bijvoorbeeld door het afdekken van de hopen. In de meest gebruikte methode van gestorte bietenhopen worden de hopen niet afgedekt, tenzij vorst wordt verwacht. Het permanent afdekken van bieten heeft als nadeel dat de temperatuur in de hoop te hoog wordt en dit heeft kwaliteitsverlies tot gevolg. Voederbietenhopen worden ook wel d.m.v. inslurven/baggen bewaard. Dit zal het invliegen van bladluizen tegengaan, maar of al aanwezige blad- of wortelluizen dit inslurven al dan niet overleven is niet bekend. Het versnipperen van voederbieten samen met mais zal de minste problemen opleveren met bladluizen, maar dit is ook de minst aantrekkelijke methode voor wat betreft de voedingswaarde en smakelijkheid van voederbieten voor melkvee. 


\subsection{De effecten van de teeltvoorschriften en eventuele vervroeging van de datum waarop bewaarhopen niet meer zijn toegestaan}

Omdat een eventuele aanpassing van de teeltvoorschriften met een vervroeging van de uiterste bewaardatum wordt bediscussieerd, is het wenselijk een inschatting te kunnen maken van het effect dat zo'n vervroeging heeft op de verspreiding van bietenvergelingsvirussen vanuit deze bewaarhopen. Hier is echter moeilijk een algemene inschatting van te maken. Dit hangt namelijk zeer af van het klimaat gedurende de winter en het voorjaar, met name van de temperatuur. Na een zachte winter kan de vervroeging een groot effect hebben wanneer juist in de tweede helft van maart regelmatig temperaturen van boven de 10 à $12{ }^{\circ} \mathrm{C}$ voorkomen. Na een strenge winter en relatief lage temperaturen in de tweede helft van maart zullen er zeer weinig bladluizen vliegen en is de kans op verspreiding van plantenvirussen gering. Dit is op dit moment een inschatting en voor deze specifieke situatie vanuit bietenhopen zijn er geen langdurige waarnemingen en/of modellen beschikbaar. Ook zal voor dit punt een betere analyse van de in bewaarhopen aanwezige bladluizen noodzakelijk zijn omdat verschillende bladluissoorten andere optimale temperaturen en omgevingsfactoren (vochtigheid en wind) hebben voor migratie. 


\section{Literatuur}

Asare-Bediako, E., Jones, J.E., Hambidge, A.J., Stevens, M., Mead, A., Jenner, C.E., Walsh, J.A., 2020. The incidence of turnip yellows virus in oilseed rape crops (Brassica napus L.) in three different regions of England over three consecutive growing seasons and the relationship with the abundance of flying Myzus persicae. Annals of Applied Biology 176, 130-137.

Bell, J.R., Alderson, L., Izera, D., Kruger, T., Parker, S., Pickup, J., Shortall, C.R., Taylor, M.S., Verrier, P., Harrington, R., 2015. Long-term phenological trends, species accumulation rates, aphid traits and climate: Five decades of change in migrating aphids. Journal of Animal Ecology 84, 21-34.

Gray, S., Gildow, F.E., 2003. Luteovirus-Aphid Interactions, Annual Review of Phytopathology, pp. 539-566.

Hani, A., 1988. The Viruses, Virus Yellows Monograph. Institut International de Recherches Betteravieres, Brussels, Belgium, pp. 9-18.

Heathcote, G.D., Cockbain, A.J., 1966. Aphids from mangold clamps and their importance as vectors of beet viruses. Annals of Applied Biology 57, 321-336.

Heijbroek, W., 1984. De vergelingswaarschuwingsdienst, 25 jaar geïntegreerde bestrijding.

Hille Ris Lambers, D., 1972. Aphids: their life cycles and their role as virus vectors, in: De Bokx, J.A. (Ed.), Viruses of potatoes and seed potato production. Pudoc, Wageningen, pp. 36-56.

Hogenhout, S.A., Verbeek, M., Hans, F., Houterman, P.M., Fortass, M., Van der Wilk, F., Huttinga, H., Van den Heuvel, J.F.J.M., 1996. Molecular bases of the interactions between luteoviruses and aphids. Agronomie 16, 167-173.

Hossain, R., Menzel, W., Varrelmann, M., 2019. Virus yellows in sugar beet - Biology and infestation risk. Zuckerindustrie 144, 665-672.

Jiménez, J., Tjallingii, W.F., Moreno, A., Fereres, A., 2018. Newly distinguished cell punctures associated with transmission of the semipersistent phloem-limited beet yellows virus. Journal of Virology 92.

Johnson, C.G., 1954. Aphid migration in relation to weather. Biol Rev 29, 87-118.

Katis, N., Gibson, R.W., 1984. Transmission of beet mosaic virus by cereal aphids. Plant Pathology 33, 425427.

Labonne, G., Lupoli, R., Quiot, J.B., Yvon, M., 1992. The transmissibility of a potyvirus by an aphid vector: reliability of measurements under controlled conditions. Annals of Applied Biology 120, 269-278.

Leather, S.R., 1993. Overwintering in six arable aphid pests: a review with particular relevance to pest management. Journal of Applied Entomology 116, 217-233.

Leather, S.R., 2015. Onwards and upwards - aphid flight trends follow climate change. Journal of Animal Ecology 84, 1-3.

Limburg, D.D., Mauk, P.A., Godfrey, L.D., 1997. Characteristics of beet yellows closterovirus transmission to sugar beets by Aphis fabae. Phytopathology 87, 766-771.

Peiffer, M.L., Gildow, F.E., Gray, S.M., 1997. Two distinct mechanisms regulate luteovirus transmission efficiency and specificity at the aphid salivary gland. Journal of General Virology 78, 495-503.

Semal, J., 1956. Transmission of beet mosaic virus from Stellaria media and Capsella bursa-pastoris by Myzus ascalonicus Doncaster [26]. Nature 178, 501-502.

Stevens, M., Freeman, B., Liu, H.Y., Herrbach, E., Lemaire, O., 2005a. Beet poleroviruses: Close friends or distant relatives? Mol. Plant Pathol. 6, 1-9.

Stevens, M., Patron, N.J., Dolby, C.A., Weekes, R., Hallsworth, P.B., Lemaire, O., Smith, H.G., 2005 b. Distribution and properties of geographically distinct isolates of sugar beet yellowing viruses. Plant Pathology 54, 100-107.

Stevens, M., Smith, H.G., Hallsworth, P.B., 1994. Identification of a second distinct strain of beet mild yellowing luteovirus using monoclonal antibodies and transmission studies. Annals of Applied Biology 125, 515-520.

Trebicki, P., 2020. Climate change and plant virus epidemiology. Virus Research 286.

Tsitsipis, J.A., Mittler, T.E., 1976. DEVELOPMENT, GROWTH, REPRODUCTION, AND SURVIVAL OF APTEROUS VIRGINOPARAE OF APHIS FABAE AT DIFFERENT TEMPERATURES. Entomologia Experimentalis et Applicata 19, 1-10.

van der Peet, G., Leenstra, F., Vermeij, I., Bondt, N., Puister, L., van Os, J., 2018. Feiten en cijfers over de Nederlandse veehouderijsectoren 2018. Wageningen Livestock Research Rapport 1134, p. 110.

van der Werf, W., 1988. Yellowing viruses in sugarbeet; epidemiology and damage. Thesis Landbouwuniversiteit Wageningen, 31 mei 1988. 
Verbeek, M., Piron, P.G.M., Dullemans, A.M., Cuperus, C., Van Der Vlugt, R.A.A., 2010. Determination of aphid transmission efficiencies for N, NTN and Wilga strains of Potato virus Y. Annals of Applied Biology 156, 39-49.

Walters, K.F.A., 1987. Forecasting the immigration of aphids into potato crops, Conference on Pests in Agriculture, Paris, pp. 587-594.

Zhou, X., Harrington, R., Woiwod, I.P., Perry, J.N., Bale, J.S., Clark, S.J., 1995. Effects of temperature on aphid phenology. Global Change Biology 1, 303-313. 

Correspondentie adres voor dit rapport: Postbus 16

6700 AA Wageningen

T 0317480700

www.wur.nl/plant-research

Rapport WPR-3740087100-20-2

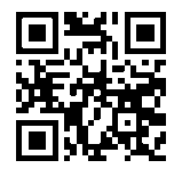

De missie van Wageningen University \& Research is 'To explore the potential of nature to improve the quality of life'. Binnen Wageningen University \& Research bundelen Wageningen University en gespecialiseerde onderzoeksinstituten van Stichting Wageningen Research hun krachten om bij te dragen aan de oplossing van belangrijke vragen in het domein van gezonde voeding en leefomgeving. Met ongeveer 30 vestigingen, 6.500 medewerkers ( $5.500 \mathrm{fte}$ ) en 12.500 studenten behoort Wageningen University \& Research wereldwijd tot de aansprekende kennisinstellingen binnen haar domein. De integrale benadering van de vraagstukken en de samenwerking tussen verschillende disciplines vormen het hart van de unieke Wageningen aanpak. 